\title{
Wataniyya as Antidote to Sectarianism
}

\author{
JENS HANSSEN
}

Come let us join together, $\mathrm{O}$ brothers

By commitment and faith allied to one another

Giving ourselves, our devotion to show, So rise oh heroes! To the battle now go ...

Love of birthplaces [al-awtan] is an article of faith.

—al-Tahtawi, Wataniyyat, $1855^{1}$

When the Orientalist Bernard Lewis lamented that the word watan - though apparently inferior to European and Islamic cognates like la patrie and Vaterland, al-umma and al-milla-had helped destroy "the universal Islamic monarchy of the Turkish sultans," his Ottoman nostalgia meant to dismiss the "patchwork quilt of soi-disant nation-states" that gained independence in the mid-twentieth century. ${ }^{2}$ What interests us, by contrast, is how national historians sought to convince their own emergent constituencies that geographically ill-defined terms mattered and corresponded to distinct territories of belonging and attachment. For if "Syria" and "Lebanon" became imaginable national territories in the twentieth century, it was not because Europeans invented them. From the perspective of conceptual 
history, the term that came to challenge religious visions of colonial and imperial rule was al-watan.

Hindsight has given at once too much and too little credit to al-Bustani's conceptual innovations. ${ }^{3}$ al-Bustani's particular use of language and history in Nafir Suriyya was triggered by the event of the civil war. For him the issue was less to determine the (Christian) essence and cultural ownership of Syria, as francophone scholars associated with the Jesuits in Beirut did. Rather al-Bustani championed a transconfessional contract where all of Syria's religious communities were equal before Ottoman law, everyone felt included but also knew their place. It was in this context that he decided to dust off the term al-watan - "the most pleasant derivative word adorning the Arabic language"-in favor of available, but by now differently connoted, alternatives. ${ }^{4}$ By choosing watan al-Bustani effectively avoided what Koselleck called in the European context "the diachronic semantic thrust of theological" alternatives and steered his ecumenical messianism toward love of the homeland. Conversely, only the nation form would enable ecumenical religiosity. Invested with new political meaning, particularly in relation to the forces that he posited had given rise to the civil war (forces that only much later acquire the seemingly stable label of "sectarianism"), the introduction of al-watan and the attachment to it, hubb al-watan, then was a conscious political act with a view to set the agenda for how the event should be interpreted and how to frame the future of his afflicted society.

Prior to the civil war in I860, al-watan had already undergone significant semantic transformation. al-watan had traveled from al-Jahiz's (d. 869) famous, if contested, treatise al-Hanin ila al-awtan (Longing for one's homelands) to the great dictionaries of Ibn Manzur (d. I3II-I2), to Lisan al-Arab, and to Murtada al-Zabidi's Taj al-Arus (I770s-80s). ${ }^{6}$ These and other instances 
awtan (pl. of watan) implied one's home, the place of birth or residence. Ottoman sultans and Persian shahs may have deployed the term to belittle their rivals or regional insurgencies.? But the term did not feature in the Circle of Justice or any of the Advice to the Prince literature. ${ }^{8}$

Ottoman diplomats stationed in Paris during the French Revolution experimented with translating the republican slogan patrie but were reluctant to endorse it given the threat such concepts posed to their young sultan. ${ }^{9}$ If the choice of translation fell on vatan, it may have still had the earlier negative connotations of the enemy's parochialism. But when foreign minister and former Ottoman ambassador to Paris, Mustafa Reşid Pasha (I80o-I858), famously announced that the state henceforth would "guarantee insuring to our subjects perfect security for life, honor, and fortune" in the Gülhane Reform Edict of 1839 , he also called upon all Ottomans to help "defend the vatan." of the Tanzimat, then, deployed the term much like al-Bustani would in Nafir Suriyya: as an ennobling concept of attachment and a political field of rights and duties.

Rif 'at al-Rifa i al-Tahtawi (I8OI-73) was more attracted to the July i83o Revolution in general and the patriotism it espoused in particular than the Ottoman eyewitnesses of the French Revolution had been in Paris in the 1790 s. ${ }^{\text {II }}$ Having spent 1826 to I83I in France, he chronicled the overthrow of the Bourbon monarchy and diligently translated the new French Constitutional Charter, including most elements of the Declaration of the Rights of Man and Citizen of $1789 .{ }^{12}$ At a time when his patron, the ruler of Egypt Mehmed Ali Pasha, began challenging the authority of the Ottoman sultan, culminating in his military campaign in Bilad al-Sham, al-Tahtawi could imbue his writings with a critique of the injustices of the Bourbon Restoration and the excesses of monarchical rule more generally. 
Geopolitics aside, the sense of cultural recovery and political reclamation that undergirded the writings and translations by Nabda figures like al-Tahtawi and al-Bustani also predisposed them to the spirit of the rights of man, social justice, and freedom of conscience expressed in the French Revolution. ${ }^{13}$

The Egyptian's wataniyya quotation at the beginning of this chapter suggests a kind of law of nature that required no further elaboration as to why and how this patriotic love works to be part of - much less an enactment of - faith, or, indeed, the faith. For all his appropriations of French Enlightenment thought, alTahtawi did not develop the concept of bubb al-watan until his late works. ${ }^{14}$ By this time he had developed neo-Platonic and Hobbesian ideas of the state as the embodiment of the watan, a human organism in which the head represents the sovereign, the organs the government, and the limbs the military. While for al-Tahtawi Egypt's territoriality appeared as a fact of natural history, the function of the Arabic language was to raise faith in the modern state. ${ }^{15}$

Arguably, the relationship between territoriality, the state, and the Arabic language was far more fraught in Nafir Suriyya than in al-Tahtawi's writings, and it is to al-Bustani's credit that he openly grappled with these tensions. al-Bustani addressed his readers as abna' al-watan - compatriots - which we render as "countrymen" in our translation, and signed each of the eleven issues of Nafir Suriyya anonymously as a mubibb al-watan-"a lover of the homeland," or "a patriot." Here and in Mubit alMubit he called his pamphlets wataniyyat. As with the ascription for his pamphlets, al-Bustani adopted one of the Nahda's key slogans- "Love of the homeland is an element of faith" (bubb alwatan min al-iman) - from Tahtawi's wataniyyat, perhaps because they were reproduced in Hadiqat al-Akbbar in the late 1850 . ${ }^{16}$ Like 
al-Tahtawi, al-Bustani claimed that the aphorism had badith status. ${ }^{17}$ The Quranic term al-iman incorporates both the act and the content of faith. ${ }^{18}$ For al-Bustani patriotism demanded a leap of faith, a commitment to loyalty even in adversity. Yet, he was mindful of any fatalism that this kind of faith might generate.

Perhaps quoting from Surat al-Ra'd, al-Bustani reminded his readers that "God will not change the state of a people unless they change themselves." In other words, mere faith in the homeland was not sufficient. What is required is something much more proactive: love. ${ }^{19}$ al-Hubb is juxtaposed to all the ills of his society: selfishness, revengefulness, fanaticism, and idleness; but it also did work that no amount of international pity and charity could provide. Based on al-iman, love is "the magnet" that attracted diverse people to their homeland. Selfless, or unselfish, love must conquer the violent passions and rein in its ignorant perpetrators so that the homeland can guarantee ecumenical religiosity in this "Babel of religions, races, and confessions" that was "Syria."

In Nafir Suriyya, al-Bustani recognized that "patriotism is an element of faith" was a concept liable to usurpation and abuse. But it was his nemesis, Ahmad Faris al-Shidyaq, who launched a blistering critique of "the false patriot." The false patriot would extol the virtues of the homeland, its natural beauty, its culture, and its history but would have nothing but contempt for his neighbors and compatriots, all the while reciting "to love one's homeland is part of faith." Shidyaq charged that there were very few patriots whose concern for the country was genuine. But when these few criticized their compatriots, they would do so as "kind educators and tender guardians." For them "life is not enjoyable if wealth is not shared by all." If "some people praise without being really concerned and some 
are concerned without praise," Shidyaq deemed "the latter are better." ${ }^{21}$

Shidyaq may have considered al-Bustani a "kind educator," given how Nafir Suriyya insisted that "the secret lies in the dweller-not the house." ${ }^{22}$ The affective registers of loyalty that his pamphlets articulated did not just echo the official Tanzimat discourse emanating from Istanbul. They were significantly altered: whereas Ottoman and Egyptian reform discourse offered subjects (ri'aya) equality in return for loyalty to the state, al-Bustani's bubb-al-watan, "patriotism," most powerfully articulated in the fourth issue of Nafir Suriyya, promoted a contract of rights and duties between the inhabitants and their homeland. What mattered most was not the state but "the welfare of the homeland." The role of the state was important but external to the contract itself. This shift challenged the traditional legal concept of subject, ra' iyya (pl. al-ri aya), and Nafir Suriyya issued the term only once. ${ }^{23}$ Instead he often used the religiously inflected 'ibad (subjects), ahali (commoners), or bani (folks) and their derivatives, which were popular in Bilad al-Sham but had no legal standing. Nor did he speak of or for $a l-s h a a^{a} b$ - the concept of "the people" emerged in Arabic political discourse only after $1862 ;^{24}$ he also introduced the liberal concept of al-insanthe human being - which came to acquire legal status in international law and human rights discourse in the twentieth century.

The "compatriots" were divided into two types: the 'uqala', the responsible thinkers, and the awbash, the hoodlums who "trade patriotism for fanaticism and sacrifice the well-being of the homeland for personal interests." ${ }^{25}$ Although they did not "deserve to belong to the homeland," the whole reason for the anguished patriotism al-Bustani expressed in Nafir Suriyya was that, by hook or by crook, warts and all, all compatriots are in it together. As Bou Ali has put it, drawing on Lauren Berlant, "love 
as a political rhetoric meant [for al-Bustani] to empower the national subject while acknowledging the ill-fate of belonging to a nation. ${ }^{26}$

The way love and faith sustained al-watan in Nafir Suriyya worked both on a biographical and on a societal level. For al-Bustani, the religious transgressor and cultural reformer, al-watan promised a secure space against violent passions and social apathy. Internal exile played a crucial role in al-Bustani's political imagination as he reclaimed personal as well as political sovereignty through the concept of al-watan. As a convert, he knew that identities were not fixed, and as a teacher with an evangelical disposition, he believed that people could overcome even their most basic instincts.

\section{FIRST EXPRESSIONS OF ANTISECTARIANISM?}

There is a difference between someone who identifies prejudices and someone who identifies with a prejudice.

$$
\begin{array}{r}
\text {-Salim al-Bustani, "al-Gharadh," } \\
\text { al-Finan (1870) }
\end{array}
$$

The most urgent task Butrus al-Bustani set himself with Nafir Suriyya was to name and shame the condition that stood in the way of patriotism and led to the violence. This task was all the more difficult because, for all his interest in the socialhe coined the term al-bay'a al-ijtima'iyya here-the concept of sectarianism did not exist yet, neither as a principle of rule nor as one of social critique. al-Ta' ifiyya - the abstract noun for the Lebanese system of sectarian political representation-was introduced much later and institutionalized only in the French Mandate period. ${ }^{27}$ In Nafir Suriyya, the noun ta' ifa/tawa' if contended with others and first appeared in al-Bustani's analysis 
only in relation to well-organized and productive animal collectives - ants, bees, and silkworms. ${ }^{28}$ In the last three issues, al-ta' ifilal-ta' ifiyya appear as adjectives among others-like personal (shakbsi, nafsani, dhati), familial ('a'ili), and confessional (madbhabi) — to specify the scourges of enmities ('adawat), factionalisms (tahazzubat), self-interests (ghayat).

It was the noun al-gharadh (pl. al-aghradh) that appeared most frequently and most unexpectedly in those passages in which al-Bustani grappled with what we today call sectarianism. ${ }^{29}$ We consider gharadh/aghradh to designate sectarianism as understood today, but in order to avoid overdetermination, we decided to translate the term in the context of how al-Bustani used it, as blind "prejudice" in favor of some predetermined group identity or, in some instances where political factionalism is explicitly invoked, as partisanship. If, as Kosellek has argued, history does not depend on language to happen, then sectarianism can exist avant le mot. al-Bustani explained the "fanaticism" and "factionalism" that led to the civil war as surface phenomena unleashed because Syrians "surrendered" to their "prejudices." But identifying gharadh/aghradh as the ultimate causation, his analysis remained limited to flaws in individual human behavior: unwillingness to reflect on the consequences of one's action, and the betrayal of traditions of neighborliness, as well as the epoch-defining spirit of altruism, public welfare, and civic responsibility. If secularism became the dominant panacea of sectarianism in the twentieth century, al-Bustani advocated a return to "true religion."

The year i86o continued to haunt the Beiruti Nabda long after al-Bustani stopped writing his pamphlets, and al-gharadh remained a conspicuous category of analysis to explain the violence in terms of "uncontrolled human instincts." In a lengthy 
article for al-finan his son Salim al-Bustani revisited al-gharadh with the passionate introspection that characterized many of his fictional writings. Although he returned to many of Nafir Suriyya's themes, he was much less evangelical in his editorials than his father had been. It had been a decade since the civil war. The Ottomans had pacified Bilad al-Sham and economic and cultural life had resumed in Beirut, and he expressed frustration that partisanship and prejudices persisted. In fact, he realized that as soon as someone "defames" him with "spears of reproach" for his writings, he blames it on "ugly prejudice in his bile." He wondered if this response made him any better than those he criticized. How could he escape the temptation or charge of prejudice and partisanship if he and his father were so harsh in their judgment of their compatriots? Did patriotism not engender new forms of harmful passions? Having set up the problem as a bodily condition-located in the bile - the article justified their social criticism. Being partial to the common good is noble but "the hero of the age is patient in all situations." Still, prejudice against the "conscripts" of partisanship was legitimate. "The quality of rational persons depends on their ability to consider time and place" both in praise and in condemnation. "Prejudice" may have many sources: "profit, kinship, love, loss, hatred, envy, proclivity for revenge, religion, conditions of race, and distress." Some are good and necessary. For example, "if one tribe attacks another, the defending tribe must adhere to gharadh in order to defend oneself in a unified way." In such instances gharadh is best rendered as "personal interest." But generally, Salim al-Bustani insists, gharadh should not be tolerated. Thus, "factional mobilization for one tribe against another, or devotion to a religion based on exclusive belonging and enmity of other religions, jeopardizes truth and justice. ${ }^{{ }^{1}}$ 
The Bustanis' line of argument may strike the reader as somewhat naïve. It certainly does not provide answers to current problems of sectarianism. But, as Ussama Makdisi has argued, antisectarian dispositions emerged in their writings starting with Nafir Suriyya, even though there was-again-no name for it yet..$^{22}$ If sectarianism and antisectarianism existed in nineteenth-century Bilad al-Sham before anyone had a word for it, then this has repercussions for the relationship between history and language in the Nabda and beyond. To be sure, semantics alone do not constitute discourse, but discourse analysis without historicizing language use also impedes the meaningful translation of historical texts such as Nafir Suriyya. And it is to the translation of this text that the second part of this book now turns. 